\title{
Umutsuzluk Ölümleri ve Kapitalizmin Geleceği
}

Deaths of Despair and the Future of Capitalism

Erdem SEÇİLIŞs

Geliş tarihi: 12.03.2020, Kabul tarihi: 12.04.2020, Basım tarihi: 10.05.2020

\section{Öz}

Bu çalışma, Anne Case ve Angus Deaton'ın eseri olan “Umutsuzluk Ölümleri ve Kapitalizmin Geleceği” isimli kitabın bir değerlendirmesidir. Çalışmada, kitabın kurumsal çerçevesi kapsamlı bir şekilde özetlenecek ve yazarların yaklaşımı irdelenecektir.

Anahtar Kelimeler: emek, ücret, kapitalizm

JEL Kodlar1: J01, P1

\begin{abstract}
This article is a review of the book "Deaths of Despair and the Future of Capitalism" by Anne Case and Angus Deaton. This review will summarize the theoretical framework of the book comprehensively and provide an examination of the authors' approach.
\end{abstract}

Keywords: labor, wage, capitalism

JEL Codes: J01, P1

2015 y1lında Nobel ekonomi ödülünü kazanan Angus Deaton, 2013 yılında yayınlanan "Büyük Firar (2013)" adlı kitabında ilerleme ile eşitsizlik arasındaki ilişkileri irdelemiştir. Deaton'a göre ilerleyenler yani kaçanlar firarlarının ardında insanlar bırakır. Bu insanlardan kimileri şanslı kimleri ise talihsizdir. Firar bazı firsatlar yaratmıştır ama herkes bu firsatlardan istifade edecek donanıma ya da kararlılı̆ga sahip değildir. Bu nedenle yazara göre ilerlemenin hikayesi aynı zamanda eşitsizliğin de hikayesidir. Deaton aktarılan perspektifteki çalışmasını önceki araştırmalardan farklı bir bağlama oturtur. Zenginlik, eşitsizlik, sağlık ve varlık kavramları çerçevesinde girift bir örüntü kurgular. Böylece kalkınmanın yarattığı adaletsiz varlık dağılımının sağlık hizmetlerinden istifade etmek hususunda yarattığ1 dezavantajlı durumu işaret eder. Ancak kitabın geneline bakıldığında insanlık tarihinin özellikle son 250 yılında tecrübe edilen gelişmelere sıklıkla dikkat çekildiği ve tecrübe edilen dönüşümün müspet etkilerinin öne çıkartıldığ1 vurgulanmalıdır. Yazara göre kapitalizm ve küreselleşme yoksulluktan kurtulma sürecinde

\footnotetext{
${ }^{1}$ Hacettepe Üniversitesi İ̈BF Maliye Bölümü, Doç.Dr. ies@hacettepe.edu.tr https://orcid.org/0000-0002-5331-8122
} 
önemli rol oynamıştır. Diğer bir ifadeyle eşitsizliğin kaynağ1 olan firarlar ilerlemenin kaçınılmaz bir aşamasıdır.

Angus Deaton'ın Anne Case ile birlikte yazdığ1 "Umutsuzluk Ölümleri ve Kapitalizmin Geleceği (2020)" adlı kitapta ise kapitalizme ilişkin daha kara bir öykü anlatıldığını değerlendirmek olanaklıdır. Yazarlar 2020 yılında yayınlanan kitapta yoğun bir kapitalizm eleştirisine girişerek küreselleşme, teknolojik dönüşüm, umutsuzluk ve ölüm arasındaki ilişkilere odaklanır. Özellikle günümüz Amerika Birleşik Devletleri'ni irdeleyerek tecrübe edilen tekinsiz sosyo-ekonomik durumun vahametini gözler önüne serer. Ancak yine de eserin kapitalizmin mutlak bir reddini imlediğini söylemek olanaklı değildir. Yazarlar kapitalizme ve serbest piyasa ekonomisine olan inançlarını korumaktadır. Ancak müesses iktisadi örgütlenmeyi rralayan kurumların kamu yararını gözetecek şekilde yeniden örgütlenmesi gerektiğini işaret ederler.

Kitap giriş kısmı ve onu takip eden 4 bölümden oluşmaktadır. Giriş kısmı "Büyük Firar" kitabından esinle başlar. Deaton önceki eserinde 20.yüzyllın en temel gelişmelerinden biri olarak ölüm oranlarındaki düşüşü işaret etmiştir. Oysaki 2014 yllında giriştikleri araştırmada orta yaşlı beyaz Amerikalılar arasında ölüm oranlarının artış gösterdiğini fark ederler. Bu onlar için şaşırtıcı bir göstergedir; bizlere sürekli sunulan kalkınma hikayesinin doğru olmadığını sembolize eden bir imdir. $\mathrm{Bu}$ nedenle araştırmalarını derinleştirmeye karar verir ve ölüm oranlarındaki artışın kökenlerini irdelerler. Sonuçta üç nedenle ölümlerin yaygınlaştı̆̆ını saptarlar. Bunlar intihar, aşırı dozda uyuşturucu kullanımı ve alkole bağlı karaciğer hastalığıdır. "Yazarlar bu unsurlardan kaynaklanan can kayıplarını "umutsuzluk ölümleri" olarak betimlerler ve bu ölümlerin arkasındaki ekonomik ve sosyal dinamikleri çözümlemeye girişirler."

Öncelikle umutsuzluk ölümü nedeniyle yaşamını yitirenlerin önemli bir kısmının üniversite mezunu ${ }^{2}$ olmadığını tespit ederler. Ancak bu ayrım sadece ölüm oranlarına yansımamıştır; yaşam kalitesinden zihinsel rahatsızlıklara, kazançtan toplumsallaşmaya üniversite mezunu olanlar ile olmayanlar arasında büyük bir ayrışma tecrübe edilmiştir. Neredeyse üniversite eğitiminin Amerika'yı ikiye böldügünü söylemek mümkündür. Ancak kitap tüm Amerikalıların hikayesini anlatmaz. Afrika kökenli Amerikalılar ile Hispanik olmayan beyaz Amerikalıların öyküsü bir noktada ayrışır. Afrika kökenli Amerikalıların hayatında 1970'lerde ivmelenen sivil haklar hakaretinin etkisiyle kısmi iyileşmeler deneyimlenmiştir. Kuşkusuz ulaşılan nokta hala adil olmaktan çok uzaktır; ancak uçurumun derinliğinin kısmen de olsa azaldığını değerlendirmek mümkündür. Hispanik

\footnotetext{
2 "the four-year college degree" ifadesi Türkçe metni akılcı kılmak amacıyla "üniversite mezunu” şeklinde çevrilmiştir.
} 
Amerikalılar için de benzer bir değerlendirme yapılabilir. Oysaki 25-64 yaş arası Amerikalıların \%62'sini oluşturan Hispanik olmayan beyazların üniversite mezunu olmayan \%62'si için aynı şeyleri söylemek olanaklı değildir. Yazarlar kitapta bu kitleyi analiz eder. Beyaz işçi sınıfinın son 50 yıldır yaşadığı refah kaybını araştırır. Onların yaşamlarını daha zor hale getiren ekonomik ve sosyal güçlere odaklanır.

Bu güçler arasında evlilik birliğine olan inancın yitmesi ve dinsel bağların zayıflaması gibi toplumsal norm değişimleri dikkat çeker. Ancak yazarlar için asıl önemli olan çalışan kesimin yaşamını değiştiren dıssal faktörlerdir. Ücretlerdeki düşüş bu noktada önemli bir etken olarak öne çıar. Üniversite mezunu olmayan beyaz erkeklerin satın alma gücü (ülke genelinde kişi başına düşen mili gelir artmasına rağmen) 1979-2017 yılları arasında büyük ölçüde azalmıştır. Yaratılan yeni işlerden lise mezunlarının payına düşen kısım göreli olarak çok azdır; iş sahibi olanlar ise önce daha niteliksiz işlere kaydırılımıs, daha sonra ücretleri azaltılmış ve bir noktada iş gücünden ayrilmak zorunda bırakılmıştır.

Ek olarak, büyük şirketler devri kapanmış; dış temin-taşeronluk-fason üretim gibi mekanizmalar yaygınlaşmıştır. Bu tip işlerde düşük ücretli olarak çalışanlar organizasyonun parçası olmanın verdiği hazzı ve gururu ve dolayısıyla aidiyet hissini yitirmiştir. Yazarlar istihdamın bir toplumsal içerme vasitası olarak önemini vurgular. Bu nedenle işini ve/veya aidiyet duygusunu yitiren emekçi sadece para kaybetmez; geleneklerini, normlarını ve rutinlerini de yitirir. Parasını, kurumunu, ailesini, kendine olan saygisın kaybeden emekçinin gelecekten beklentisi kalmaz; büyük bir umutsuzluk içine düşer. $\mathrm{Bu}$ umutsuzluk ise intihara giden yolu açar.

Bu noktada yazarlar şu soruyu sormaktadır: "Ekonomi neden işçi sınıfın mahvına neden olmaktadır?". Onlara göre küreselleşme ve teknolojik değişim Amerika'da eğitimsiz işgücünün değerini azaltmış ve işçi sınıfi üyelerini ikinci sınıf vatandaş kılmıştır. Halbuki diğer zengin ülkelerde durum daha farklıdır; işçiler yaşanan menfi değişimlerden göreli olarak bağışık kalmıştır. Amerika'da tecrübe edilen ayrışmanın başlıca sebeplerinden biri yazarlara göre sağllk hizmetleri sistemidir. Sağlık hizmetleri, politik muhafaza vasıtası ile geliri hastane ve ilaç şirketleri lehine yeniden dağıtan bir kuruma dönüşmüştür. Özellikle opioid ${ }^{3}$ türü ilaçların devlet izni ile piyasada rahatça ulaşılır hale gelmesi bağımlı sayısının artmasına neden olmuştur. Sağlık endüstrisi bir kanser misali ekonomiyi sekteye uğratmış ve kamu tarafindan harcanan onca kaynağa rağmen Amerika'da batı dünyasının en olumsuz sağlık çıtıları gözlemlenmiştir. Yazarlara göre bu sürecin başlıca sorumlularından biri "anti-Robin Hood" rolüne bürünmüş politikacilardır. Politikacıların yarattı̆̆ yeni düzenlemeler kartel ve tekellerin yaygınlaşmasına

\footnotetext{
${ }^{3}$ Opioid orta dereceli ve şiddetli ağrıların giderilmesinde kullanılan morfin, kodein, metadon, meperidin, pentazosin ve fentanil vb. verilen isimdir (Can, 2005).
} 
neden olmuş; bu ise Amerika'nın diğer zengin ülkelerden çok daha köklü problemler deneyimlemesine yol açmıştır.

Yazarlar bu tespitlerden yola çıkarak eşitsizliği bir neden olarak değil bir sonuç olarak görürler. Topluma, ekonomiye ve siyasete sirayet eden rant arayışı kaçınılmaz biçimde sağlık sistemine de sızmıştır. Araştırmacılara göre sağlık hizmetleri sisteminde baskın bir aktör haline gelen "hırsızları durdurmanın doğru yolu çalmalarına engel olmaktır". Opioidlerin kar amaçlı olarak suistimal edilmesinin önüne geçilmeli, yabancı doktorların Amerika'da çalışması kolaylaştırılmalı ve bankerlerin yasa yapması engellenmelidir.

Kitabın birinci bölümü geçmişin irdelenmesine ayrılmıştır. Yazarlar 20.yüzyılda sağlık, ekonomi ve eğitim alanlarında olağanüstü ilerlemeler yaşandığını ifade eder. Tecrübe edilen onca felakete ve krize rağmen toplumsal refahta gelişme kaydedilmiştir. 20.yüzyılda Amerika'da doğumda yaşam beklentisi 49 yıldan 77 yıla yükselmiştir. 1900'lü yıllarda ölümlerin üç temel nedeni mevcuttur. Bunlar pnömoni, tüberküloz ve gastrointestinal enfeksiyonlardır. Ancak yüzyılın ortasında aşıların ve antibiyotiklerin gelişimi bu hastalıkların yayılımına ket vurmuş; genç yaşta ölümler önemli ölçüde azalmıştır. Yüzyllın sonu itibari ile en yaygın ölüm nedenleri kalp hastalıkları ve kanserdir. Ancak sağllğa ve ölüme ilişkin tüm hususları yalnızca biyolojik bağlamda irdelemek indirgeyici bir yaklaşımdır. İntihar, trafik kazası, alkol, sigara, obezite, silahla vurulma, vb. sebeplerle gerçekleşen ölümlerin nedeni temel olarak biyolojik değil davranışsaldır. Yazarlara göre bu yüzden tıp ve sosyal bilimleri tamamlayıcı disiplinler olarak görmek gerekir. Son tahlilde 20.yüzyll itibari ile Amerikalıların önceki dönemlere göre hem daha uzun hem de daha iyi yaşadıklarını değerlendirmek mümkündür.

21.yüzyılda ise göstergeler değişmeye başlamış ve daha olumsuz bir tablo ortaya çıkmıştır. İlgili çerçevede özellikle Hispanik olmayan beyaz Amerikalıların orta yaşta (45-54 yaş) ölüm oranındaki artışı dikkat çekicidir. Yazarlar kitapta bu menfi değişimin nedenlerini araştırır. İrdelemeleri neticesinde intihar oranlarındaki artısın ve alkol-opioid kullanımının yaygınlaşmasının aktarılan süreçteki önemli etkilerini keşfederler. Kuşkusuz 1rk ve etnisite analizlerine girişildiğinde başlıca yaşam istatistikleri Hispanik olmayan beyaz Amerikalılardan çok daha olumsuz tabloları işaret eden dezavantajlı gruplar mevcuttur. Ancak Hispanik olmayan beyaz Amerikalılar1 özel kılan değişim trendindeki aksi yönde harekettir. Diğer gruplar için iyileşme süreci bir şekilde devam ederken Hispanik olmayan beyaz Amerikalılar için işler tersine dönmüştür. Yazarlar aktarılan nedenle bu grubun ayrıntılı olarak değerlendirilmeye muhtaç olduğunu değerlendirir.

Araştırmacılara göre orta yaşlı beyaz Amerikalılar arasında yaygınlaşan intihar vakaları ve alkol-uyuşturucu kullanımı yukarıda aktarılan trend değişiminin başlıca tetikleyicisidir. Umutsuzluk ölümlerini salgın/enfeksiyon/virüs kaynaklı yaşam kayıplarından farklı kılan unsur 
bireylerin bu ölümlerden şahsi olarak sorumlu olmasıdır. Kuşkusuz aktarılan üç tip umutsuzluk ölümü birbiri ile yakından ilişiklidir ve hepsi yaşam memnuniyetsizliğin ve mutsuzluğun bir yansıması olarak değerlendirilebilir. Özellikle 2000'li yıllarda orta yaşlı beyaz Amerikalılar için işaret edilen üç ölüm tipinin pek çok eyalette arttığ tespit edilmiştir. 1999-2017 yılları arasındaki ölüm oranları irdelendiğinde en yüksek artış yaşanan eyaletlerin eğitim seviyesinin ulusal ortalamanın altında seyrettiği West Virginia, Kentucky, Arkansas ve Mississippi olduğu gözlemlenmiştir; oranın göze çarpan ölçüde düştüğü yegane eyaletler olan California, New York, New Jersey ve Illinois'de ise yüksek eğitim seviyesi dikkat çekmektedir.

Case ve Deaton, kitaplarının "Bir Savaş Alanının Anatomisi" başlıklı ikinci bölümünde bir önceki cümlede aktarılan tespitten yola çıarak umutsuzluk ölümü riskinin üniversite mezunu olmayanlar için önemli ölçüde arttığını değerlendirirler. Örneğin, üniversite mezunu olmayan 45-54 yaş arası Kentuckyli beyazlar için umutsuzluk ölüm oranı 1995 yllında 100000 kişide 37 iken, 2015 ylında arasında 100000 kişide 137 olmuştur. Üniversite mezunları için ise ufak bir değişim gözlemlenmiştir. Benzer bir örüntünün tüm eyaletler için geçerli olduğunu söylemek mümkündür. Yazarlara göre Amerika'da kimin neden öldüğünü anlamak isteyen bir araştırmacı muhakkak eğitim meselesine odaklanmalıdır.

Kuşkusuz üniversite mezunları ile mezun olmayanlar arasında bir kazanç farkının her zaman olduğunu değerlendirmek mümkündür. 1970'lerin sonlarında üniversite mezunları, lise mezunlarından ortalama $\% 40$ daha fazla para kazanmakta iken 2000'li yıllarda bu oran \%80'e çıkmıştır. Yazarlara göre teknolojik gelişmenin iş yaşamına yön vermesi daha nitelikli çalışanlara yönelik talebi arttırmaktadır. Böylelikle işgücü piyasasında üniversite mezunları daha fazla rağbet görür hale gelmekte ve lise mezunları arasında işsizlik artmaktadır.

Üniversite mezunları ile üniversite diplomasına sahip olmayanlar arasında sadece ekonomik hayatta değil tüm alanlarda giderek daha büyük bir ayrışma tecrübe edilmektedir. Araştırmacıların deyişiyle iş yaşamında, sosyal yaşamda, kamusal alanda ve hanede eğitim durumuna göre farklı dünyalar deneyimlenen heterojen bir toplumsal yapı oluşmuştur. İşaret edilen çerçevede gelişen meritroktik örgütlenme sadece eğitimlilere fırsat tanımak suretiyle düşük eğitimli pek çok nitelikli insanın toplumsal hiyerarşi içerisinde ilerlemesine olanak bırakmamaktadır. Diğer bir ifadeyle firsat eşitliği ortadan kalkmış ve düşük eğitimliler için Amerika neredeyse yaşanmaz bir yer haline gelmiştir. 1990’lı yılların başından itibaren ölüm oranları üniversite mezunu olmayanlar için $\% 25$ artarken; üniversite mezunları için \%40 düşmüştür. Yazarlar bu ayrışmanın başlıca sebebi olarak umutsuzluk ölümlerine dikkat çekmektedir. Ek olarak üniversite mezunu olmayanların sigara içme, obez olma, hipertansiyon problemi yaşama ve kısa 
boylu olma ihtimalinin de üniversite mezunlarına göre daha yüksek olduğu gözlemlenmektedir.

Yazarlara göre emek kesiminin problemleri bir noktada hep acı üzerinden dolayımlanır ve umutsuzluk ölümlerini uyarır. Kuşkusuz acı kavramından sadece fiziksel acı anlaşılmamalıdır. Reddedilme, dışlanma, kayıp gibi hususların yarattığı sosyal acılar da insanın yaşama tutunmasını zorlaştırmaktadır. $\mathrm{Bu}$ noktalar dikkate alındığında düşük eğitimli Amerikalıların artan acılarını anlamak daha olanaklı hale gelir. Sosyal ve ekonomik yaşamdaki çözülme acıyı tetikleyerek emekçileri intihara ve bağımlılığa sürüklemektedir. Bahsedilen husus tüm Amerikalılar için geçerli olmasina rağmen orta yaşlı ve üniversite mezunu olmayan bireylerin bu problemleri daha keskin hissettiğini değerlendirmek mümkündür. Yazarlar yaptıkları araştırmada acı çektiğini söyleyen Hispanik olmayan beyaz Amerikalıların yoğunlaştığı bölgelerde umutsuzluk ölümlerinin önemli ölçüde dikkat çektiğini saptamıştır.

2017 yılında 158000 Amerikalı umutsuzluk ölümleri nedeni ile hayatını yitirmiştir. Umutsuzluk ölümlerinin önemli bir bileşeni olan intiharlar literatürde Emile Durkheim'dan beri tartışlmaktadır. Durkheim eğitimli insanların -toplumun üyelerine anlamlı bir hayat sunamamasindan kaynaklanan- intiharlara daha eğilimli olduğunu öne sürmüştür. Ona göre eğitim, intiharı engelleyen geleneksel inanç ve değerleri törpülemektedir. Oysaki günümüz Amerikan toplumunda durum bunun tam tersidir. Eğitim seviyesi düşük bireylerin kendini öldürmeye daha yatkın olduğu gözlemlenmektedir. 2017 yllinda 47000 bin Amerikalı intihar etmiştir. Şüphesiz intihara giden yolun uyuşturucu ve alkol bağımlllğından geçtiğini değerlendirmek mümkündür. Pek çok kişi tecrübe ettikleri buhranlara dayanabilmek adına çeşitli bağımlılıklara sığınırlar. Ancak bu genellikle geçici bir çözümdür; bağımlıların intihara daha meyilli oldukları gözden kaçırılmamalıdır.

2000'li yıllarda intihar oranlarının dünya genelinde düştüğü gözlemlenmiştir. Hispanik olmayan beyaz Amerikalılar için ise durum tam tersidir; intihar oranları 1990'ların sonundan itibaren tüm yaş grupları için artmaktadır. Kadınların intihar eğilimleri erkeklere göre daha düşüktür. Yazarlara göre bu kısmen kadınların daha etkisiz ölüm araçları seçmelerinden kısmen de erkeklere nispetle sosyal soyutlanmaya daha az yatkın olmalarından kaynaklanmaktadır. Ek olarak araştırmacılar Amerika Birleşik Devletleri'nde bir intihar kuşağının varllğından bahseder. Bu kuşak güneyde Arizona'dan kuzeyde Alaska'ya kadar Rocky dağları boyunca uzanır. $\mathrm{Bu}$ bölgedeki eyaletlerde nüfus yoğunluğu çok düşüktür. Ek olarak düşük nüfus yoğunluğunun gözlemlendiği bölgelerde ateşli silah sayısının yüksekliği de dikkat çekicidir. Nüfus yoğunluğunun yüksek olduğu eyaletlerde ise intihar oranlarının düşük olduğu gözlemlenir. 
Eğitim ile intihar arasındaki ilişkinin dikkat çekici diğer bir yönü Hispanik olmayan beyaz Amerikalıların deneyimlediği kuşaklar arası farklılıklardır. 1945 yllı doğumlulardan üniversite mezunu olanlar ile olmayanların intihar eğilimleri arasında kayda değer bir fark yokken; 1970 doğumlular arasında yillar geçtikçe büyük bir ayrışma deneyimlenmektedir. Alkol kullanım istatistikleri incelendiğinde ise yine eğitim seviyesinin önem arz ettiği görülmektedir. Amerika Birleşik Devletleri'nde yüksek eğitimlilerin içki içme eğilimi daha fazladır. Ancak dikkat çekici husus asıl zararlı olan dipsomani (aşırı miktarda alkol içme atağı) eğiliminin düşük eğitimliler arasında daha yüksek olmasıdır. Aşırı dozda uyuşturucu kullanımı nedeniyle gerçekleşen can kayıpları için de benzer bir tespit geçerlidir. Bu şekilde yaşamını yitiren insanların \%90’1 üniversite mezunu değildir.

Yazarlar umutsuzluk ölümlerine ilişkin göstergeleri paylaştıktan sonra ölümlerin ekonomik nedenlerini araştırmaya girişirler. Bu tip bir arayış içerisinde akla öncelikli olarak gelen nedenler yoksulluk, gelir eşitsizliği ve 2008 yilında başlayan resesyondur. Ancak yazarlar bu noktada bir şerh düşerler. Onlara göre bu hususlar çok önemli olmakla ve süreci etkilemekle birlikte umutsuzluk ölümlerindeki hızlı artışın asıl nedeni değildir. Yoksulluk göstergelerinde umutsuzluk ölümlerindeki artsşı açılklayacak ölçüde bir yükseliş yoktur. 1990-2017 yılları arasında üniversite mezunu olmayan Amerikalılar içinde yoksul Hispanik olmayan beyaz Amerikalıların sayısı yoksul Afro-Amerikalıların yarısından azdır. 2013 yllina kadar AfroAmerikalıların neredeyse umutsuzluk ölümü salgınından azade kaldığ1 düşünüldüğünde yoksulluğun süreçte pek de öncü bir rol oynamadığ1 değerlendirilebilir. Yazarların deyişiyle "ölüm fazlasıyla beyazdır". 1980’lerin başından 2008 resesyonuna kadar geçen sürede orta yaşlı beyazlar arasında yoksulluk oranı sabitken umutsuzluk ölümleri her sene artmıştır. Gelir eşitsizliği için de benzer bir değerlendirme yapmak mümkündür. 1970’lerden beri Amerika'da gelir eşitsizliği artmasına rağmen ölüm oranları düşmektedir. Oysaki 1990'dan sonra daha az eğitimli kesim arasında umutsuzluk ölümlerinde bir artış yaşanmaktadır. Örneğin New York ve California eşitsizliğin en derin tecrübe edildiği eyaletler olmasina rağmen en düşük ölüm oranına sahip bölgeler arasında yer almaktadır. Yoksulluk ve eşitsizlik gibi 2008 resesyonunun da umutsuzluk ölümlerinin temel nedeni olmadığını değerlendirmek mümkündür. Yazarlar bu ölüm tipine ilişkin yükselişs trendinin 1990'lardan itibaren başladığını ve krizin herhangi bir ayrık etkisinin gözlemlenmediğini işaret etmektedir. Elbette kriz, işsizlik ve bağımlılık arasında ilişkiler vardır; ancak yazarlara göre iş sahibi olmak tek başına umutsuzluk ölümlerine sürüklenmeyi önlemez; bu nedenle meseleye daha geniş bir perspektiften bakılmalıdır.

Yazarlar aktarılan ayrışmaların altında yatan temel etkenin eğitim olduğunu değerlendirir. Üniversite mezunu olup olmamak kimin daha iyi bir hayat yaşayacağının asıl belirleyicisidir. Sağlık problemleri ve umutsuzluk 
ölümleri esasen daha az eğitimlilerin meselesidir. Düşük eğitim düzeyine sahip bireyler ücretler, işgücüne katılım, uygun pozisyonlar ve yükselme şansı bakımından dezavantajlı pozisyondadır. Ek olarak, düşük eğitimli bireylerin emek piyasasında tecrübe ettiği menfi durumun sadece ekonomik çıktılara yansımadığı değerlendirilmelidir. İş sadece kazanç sağladığı için önem arz etmez; asıl işlevi hayata anlam katmaktır. Aile, evlilik, çocuk yetiştirme gibi kurumları besler. İyi eğitimli bireyler kaliteli okulların, nitelikli işlerin ve eğlencenin yoğunlaştı̆̆1 kentlerde toplulaşırken; düşük eğitimli insanların madunlaşarak çürüyen toplumlarda, küçük yerleşkelerde ve kırsalda yerliyurtlulaştı̆̆ gözlemlenmektedir.

Amerikan'ın yakın tarihine bakıldığında 1970'li yıllardan itibaren büyüme trendinin daha düşük seyrettiği ve eşitsizliklerin arttı̆̆1 gözlemlenmektedir. Ekonomik büyüme yavaşladıkça bölüşüm problemleri su yüzüne çıkmış; beyaz işçi sınıfının yaşam koşulları giderek kötüleşmiştir. Bu dönüşümle birlikte piyasa yalnızca yüksek eğitimlileri ödüllendiren bir yapıya bürünmüş; ekonomi sıfır toplamlı bir oyun gibi algılanmaya başlanmıştır. Faktör bazında milli gelir paylaşımı incelendiğinde aktarılan tablo daha da netleşmektedir. 1970'den beri ücretlerin milli gelir içerisindeki pay1 \%67'den \%60'a düşmüştür. Bu değişimi milli gelir büyümesinin getirilerinin sermaye sınıfına aktı̆̆1 şeklinde değerlendirmek mümkündür. Hanehalkları arasinda gelir eşitsizliği artmış; ekonomideki üretkenlik artışı beraberinde ücretlerde aynı düzeyde bir yükseliş getirmemiştir. 1979-2018 yılları arasında üretkenlik \%70 artarken, saatlik ücret sadece \%12 artmıştır. Oysaki 1979 yllına kadar üretkenlik ve işçi kazanımları birlikte yükselmiştir. Bu tarih deneyimlenen ayrışmanın miladı olarak kabul edilebilir.

1980-2000 y1lları arasında üniversite mezunlarının lise mezunlarına nispetle elde ettikleri ek kazanç iki katına çıkmıştır. Yazarlara göre 1980 sonrasında yüksek eğitim seviyesine sahip bireyler ile düşük eğitimli bireyler arasındaki farklılaşmanın temel nedeni üretimin karmaşı teknolojilere bağımlı hale gelmesidir. Bu tip bir ortamda eğitim ve bilişsel yetenekler daha kıymetli hale gelmiş; geleneksel üretim yöntemleri ve ihtiyaç duyulan emekçi profili mutasyona uğramıştır. İşaret edilen dönüşüm şüphesiz tüm dünya için geçerlidir; ancak diğer hiçbir ülkede Amerika'daki kadar köklü bir ayrışma deneyimlenmediği de gözden kaçırılmamalıdır.

İlgili çerçevede bireylerin eğitim hizmetlerine yönelik tutumu da dikkat çekmektedir. Emek talebinde gözlemlenen dönüşüme rağmen daha fazla eğitim alma yönünde bir eğilim gelişmemiştir. 1996-2007 ylları arasında üniversite eğitimi alan genç yetişkinlerin oranı değişmemiş; 2008-2017 y1lları arasında ise ancak sınırlı bir şekilde (\%6) artmıştır. Daha fazla kazanç vadetmesine rağmen gençlerin eğitime yönelmemesi kapitalist sistemde aksayan bir şeyler olduğunun göstergesidir. Bu aksama neticesinde üniversite eğitimi alanlar ile almayanlar arasındaki fark giderek daha da açılmaktadır. 
Gözlemlenen bu ayrışma sadece üniversite mezunlarının artan kazançlarından kaynaklanmamaktadır; ek olarak üniversite mezunu olmayan bireylerin kazançları da azalmaktadır. Üniversite mezunu olmayan beyaz erkekler için medyan ücretteki ortalama büyüme 1979-2007 yılları arasında ylllk \% $\%-0.2$ 'dir.

Emek piyasasındaki dönüşümü iktisadi örgütlenmenin evrimi çerçevesinde değerlendirmek mümkündür. 2.Dünya Savaşı sonrasında benimsenen refah devleti yaklaşımı ve deneyimlenen kalkınma süreci tüm dünyada emek kesimini kuvvetlendirmiştir. İmalat sanayinin yükselişi ve sendikal faaliyetlerin artışı çalışanlara daha avantajlı pozisyonlar, daha kuvvetli haklar ve daha iyi yaşam biçimleri sunmuştur. Amerika'da 1950'li yllarda işgücündekilerin \%33’ü sendika üyesi haline gelmiştir. Ancak ilerleyen dönemlerde birikim rejimi farklılaşmış, teknolojik dönüşüm ivmelenmiş ve imalat sanayi güç kaybetmiştir. Geçen yllar içerisinde sendikaların gücünün törpülenmesi çalş̧an kesimin edinimlerine ket vurmuştur. 2018'de işgücü içerisinde sendikalı olanların oran1 \%10.5'e inmiştir. İmalat sanayi işleri yok oldukça ve taşeronluk müessesi yayginlaştıkça çalışanlar arzu etmedikleri pozisyonlara kaymak zorunda kalmış; işveren ve işçi arasındaki bağlar kopmuştur. Aktarılan dönüşümde deneyimlenen kayıplar düşük eğitimli işçiler tarafından çok daha derinden hissedilmiştir.

Düşük eğitimlilerin daha az çalışma olanağı bulması ve bulsa dahi daha niteliksiz işlerde istihdam edilmesi iş yaşamının yanında hane yaşamına da sekte vurmuştur. Düşük ve yüksek eğitimliler arasındaki fark sadece emek piyasasında artmamışır; ek olarak evlilik, çocuk yetiştirme, din, sosyal aktiviteler ve topluma katılım hususlarında da eğitim seviyesinin yarattığ1 ayrışma artmaktadır. $\mathrm{Bu}$ nedenle tek başına reel gelire odaklanmak indirgeyici bir yaklaşımdır; umutsuzluk ölümlerine giden yolu çözümlemek için daha geniş bir perspektife ihtiyaç vardır. Düşük eğitimli beyazların evlilik oranı giderek düşmekte ve evlilik birliği dışında dünyaya gelen çocuk sayısı artmaktadır. İşçiler arasında birlikler çerçevesinde deneyimlenen dayanışmanın çözülmesi düşük eğitimli beyazların sosyal yaşamlarını sekteye uğratmış; ek olarak dinsel bağların zayıflaması hasebiyle bu tip organizasyonlar aracillğıyla elde edilen destek ve katkılar ortadan kalkmıştır. Yazarlara göre ailenin, toplumun ve dinin çöküşü umutsuzluk ölümleri üzerinde ücretlerdeki düşüşten daha büyük bir etkiye sahiptir. Aktarılan unsurlar toplulaştı̆ında geleneksel işçi sınıfı yaşamı yerle bir olmuştur.

Yazarlar kitabın son bölümünde kapitalizmin neden sürekli başarısız olduğunu araştırır. İlk bölümlerde aktarılan tespitlerden sonra sıra nedenlere gelmiştir. Akıllarında yanıt aranan bazı sorular vardır: Neden düşük eğitimli beyazlar aktarılan sikıntılardan muzdariptir? Neden siniflar arası farklar her geçen gün daha da artmaktadır? Yazarlar işaret edilen problemlerin önde 
gelen nedenlerinden birinin Amerikan sağllk hizmetleri sistemi olduğunu değerlendirir. Sağlık hizmetleri sisteminin maliyeti çok yüksektir. Bu maliyetler nedeni ile ücretler düşmekte, nitelikli işlerin sayıs1 azalmakta, eğitim-altyap1 yatırımları-hizmetleri aksamakta ve federal-yerel hükümetler tarafindan sağlanan kamusal mallar ve hizmetler için fon sağlanamamaktadır. Küreselleşme ve otomasyon nedeni ile tehdit altında olan işçi sınıfının refah kayıpları sağlık sisteminin sürekli yükselen maliyetleri nedeni ile daha da köklüleşmektedir. Yazarlar sağlık sisteminin maliyetlerini ekonomiye metastaz yapan bir kanser olarak nitelemektedir.

Sağlık hizmetleri dünyanın her yerinde pahalıdır ve kamu kaynaklarının sağlık sistemi aracılığıyla vatandaşların refahını yükseltmek amacı ile hüsnüniyet çerçevesinde harcanmasında bir sakinca yoktur. Ancak maalesef Amerika'da gerçekleşen bu değildir. Yüksek sağlık harcamaları vatandaşlara refah getirmeyen yalnızca şirketleri büyüten ve daha karlı kılan bir yapıya hizmet eder duruma gelmiştir. Amerika'da gayrisafi milli hasılanın \%18'i sağık hizmetlerine harcanmaktadır. $\mathrm{Bu}$ fon aktarımı nedeniyle artan kesintiler ücretlerin düşmesine ve sağlık endüstrisinin olması gerekenden daha fazla genişlemesine yol açmaktadır. İşverenlerce sağlanan sağlık sigortası nedeniyle düşük eğitimliler için iş seçenekleri azalmaktadır. Yazarlara göre sağlık hizmetlerinden taviz vermeden bu harcamaların üçte birini kesmek mümkündür.

Amerikan sağlık sistemindeki fahiş harcamaların yüksek fiyatlardan ve sağlık hizmeti sağlayıcılarına ödenen yüksek ücretlerden kaynaklandı̆̆1 görülmektedir. OECD ülkeleri ile karşılaştırmalı olarak bakıldığında özellikle yüksek doktor ücretleri dikkat çekmektedir. Benzer şekilde hemşire ücretleri, tedavi ve operasyon maliyetleri de karșlaştırmalı olarak oldukça yüksektir. İlaç fiyatlarının da (3 kat) emsal ülkelerden farkı dikkat çeker. İlaç şirketleri ise ilaçların Amerika'da geliştirdiğini ve bunun maliyetlere yansıdığını belirterek bu durumu meşru kilmaya çalışmaktadır. Oysaki araştırmalar göstermektedir ki ilaç Ar-Ge araştırmasını önemli ölçüde kamu kesimi finanse etmektedir; özel firmalar bütçelerinin önemli bir kısmını pazarlama faaliyetleri için harcamaktadır. Ek olarak, eskiden doktorlar tarafindan yönetilen hastaneler şirket yöneticilerinin eline geçmiş karlllık odaklı bir işletme mantığ ile hizmet vermeye başlamıştır. Yazarlara göre işaret edilen çerçevede sağlık hizmetleri piyasasının serbest bir piyasa olarak işlemesi olanaklı değildir. Bu nedenle sağlık piyasasında düzenleme şarttır.

Şüphesiz sağlık hizmetleri sistemi tecrübe edilen sıkıntıların tek nedeni değildir; modern kapitalizme ilişkin diğer bazı unsurlar da deneyimlenen umutsuzluğu derinleştirmektedir. Tröst karşıtı yasaların işlevsizliği nedeniyle şirketlerin piyasa gücü artmakta; bu güç hem çalışanları hem de tüketicileri sömürmek için kullanılmaktadır. Firmaların konsolide olması reel geliri işçilerden/tüketicilerden yöneticilere/sermaye sahiplerine dağıtan bir sistem 
gelişmesine neden olmuştur. Ancak yazarlar yine de kapitalizme mutlak şekilde karşı olmadıklarını; son tahlilde rekabet ve serbest piyasanın gücüne inandıklarını belirtirler. Diğer taraftan varılan noktada Amerikalı emekçilerin piyasadan fayda görmedikleri de bir gerçektir. Yazarlara göre bu problemi ortadan kaldırmak için bir kısım piyasaların gerçekten serbest-rekabetçi hale getirilmesi gerekmektedir; bazı durumlarda ise devlet müdahalesi elzemdir. Emekçileri yoksulluğa mahkum eden yukarı yönlü yeniden dağıtım mekanizmasını yıkmak ancak bu şekilde olanaklı hale gelir. Öncelikli olarak yapılması gereken kaynakların yoksullardan varsıllara yeniden dağıtımının önlenmesidir. Bunun nasıl gerçekleştirileceği ise soru işaretidir. Şirketlerin hükmettiği bir kongrede işverenlerin karlılıklarını azaltacak bu tip düzenlemelerin kabul görmesi oldukça zordur.

Son tahlilde araştırmacılara göre umutsuzluk ölümlerini azaltmak için bir şekilde eğitim seviyesi düşük Amerikalıların ücretlerindeki azalış durdurulmalı/tersine çevrilmelidir. Bunun için çeşitli politika önerileri geliştirmişlerdir: İlaç ve sağlık hizmetleri piyasası düzenleyici bir kuruluş tarafindan kontrol edilmelidir, genel sağlık sigortası sistemi işlevsel hale getirilmelidir, çalışanların şirketlerde temsili sağlanmalıdır, taşeron uygulamaları ve esnek çalışma koşulları hususlarında düzenlemeler yapılarak sendikal güçlerini yitiren emekçilerin hakları korunmalıdır, tröst ve kartel karşıtı düzenlemeler daha etkili şekilde uygulanmalıdır, emek piyasasında işverenlerin monopsoni yaratması engellenmelidir, iş yaratımına odaklanmalıdır, asgari ücrette 1 lımlı bir artı̧a gidilmelidir, şirketlerin-ticari örgütlenmelerin lobi faaliyetlerine engel olunmalıdır, eğitim sisteminde reform yapılmalı ve mesleki eğitime ağırlık verilmelidir.

Bunları başarmak için öncelikli olarak zengin azınlığı daha da zenginleştirme uğraşı bir kenara bırakılmalıdır. Case ve Deaton'ın perspektifinden daha iyi düzenlenen ve denetlenen bir kapitalizm çerçevesinde bahsedilen reformları hayata geçirmek olanaklıdır.

Kitabın genel savları toplulaştırıldığında geleneksel işçi sınıfi dinamiklerindeki dönüşümün toplumsal refah, dayanışma ve barış üzerindeki menfi yansımalarının tartışıldığını değerlendirmek mümkündür. Ancak yazarların tespitlerinin çok da özgün olduğunu söylemek maalesef güç gözükmektedir. Bu meselelerin pek çoğu farklı araştırmacılar tarafından daha önceki tarihlerde detaylı olarak irdelenmiştir. Özellikle Richard Sennett'in eserleri incelendiğinde bahsedilen dönüşümü oldukça açık bir biçimde işaret ettiği gözlemlenmektedir.

Sennett ve Cobb 1972 yılında yayınladıkları "Sınıfin Gizli Yaraları (1972)" adlı kitapta sendikaların güçlü, piyasaların nispeten istikrarlı olduğu bir dönemde işçi sınıfinın statü kaygısı nedeni ile deneyimlediği tatminsizlikleri araştırmışır. Yazarlar araştırma sonucunda çalışanların mutsuzluklarını evlatlarının sınıf atlayacakları hayali ile baskıladıklarını 
gözlemlemiştir. Sennett 1998 yılında yayınlanan "Karakter Aşınması (1998)" adlı kitabında ise teknolojik gelişim ile evrilen iş dünyası içinde kaybolan insanın hikayesinin peşine düşmüş ve yeni kapitalizmin dinamiklerini irdelemiştir. Sennett'in nihai varg1sı esnek iktidar rejimlerinin rutinleri kırarak aidiyeti törpülediği ve çalışanların karakterlerini aşındırdığı yönündedir; ona göre "iyi bir işin nitelikleriyle iyi bir karakterin nitelikleri artık örtüş(memektedir) (Sennett, 2017: 21)". İki kitap arasında geçen 26 yll bir baba-oğulun farklı umutsuzluk hikayeleri yaşamasına neden olmuştur. Hikayeler farklılaşmış; işçi sınıfının deneyimlediği sorunsalın odağı mavi yakalı emekçilerin statü kaygısından yeni nesil emekçilerin karakter aşınmasına kaymıştır. Kanımızca Case ve Deaton'ın araştırdığı günümüz umutsuzluk ölümlerinin tetikleyicisi olarak işaret edilen karakter aşınmasını değerlendirmek mümkündür.

Kuşkusuz Case ve Deaton çalışmasının odağında Hispanik olmayan beyaz Amerikalıların yer alması ve Sennett'in karakter aşınması araştırmasının geleneksel işçi sınıfını sınırlarının ötesini imlemesi hasebiyle çalışmalar arasında karşılaştırma yapmak hususunda tereddütler olabilir. Ancak kanımızca bu tip bir karşılaştırmaya girişmek hatalı bir yaklaşım değildir. Çünkü umutsuzluğa ilişkin problemlerin kökeninde ezilenlerin/mutsuzların/umutsuzların hangi sınıf içerisinde betimlendiklerinden bağımsız ve ulustan/etnisiteden/1rktan azade şekildeneoliberal politikalar ve yeni kapitalist iktisadi örgütlenme yer almaktadır. Ünlü iktisatçı Raj Chetty ve arkadaşlarının "Opportunity Insights" adlı projelerinde ulaştıkları sonuçlar bu vargının delili olarak yorumlanabilir.

Chetty ve arkadaşları Amerikan rüyasını tüm insanlara geldikleri yerden bağımsız olarak (ırk, coğrafya, aile, eğitim-kültür mirası, sınıf, vb.) toplumda daha yukarılara tırmanma firsatı sunan bir mekanizma olarak betimlemektedir. Basit bir deyişle Amerikan rüyası onlara göre bir sınıf atlama ihtimalidir. Chetty ve arkadaşları bu olasilığın 1970'lerden itibaren oldukça azaldığını gözlemlemiştir. Chetty çalışmasının "Ulusal trendler" başlı̆ı altında yanıt aranan temel soru şudur: "Çocukların üst sınıfa yükselme şansı zamanla nasıl değişti?". Araştırma sonuçları Amerikan rüyasının solduğunu göstermektedir. 1940’lı yıllarda Amerika Birleşik Devletleri'nde doğan çocukların \%90'dan fazlası ailelerinden daha fazla gelir elde ederken; bunu başaran çocuk sayısı günümüzde $\% 50$ 'lilere inmiştir. Chetty yukarı yönlü gelir hareketliliği oranlarının geçen yarım yüzyılda keskin bir şekilde düşmesine neden olan etkenin büyümenin adaletsiz bölüşümü olduğunu söyler. Ona göre aynı düzeyde ekonomik büyümenin eşit biçimde tahsis edilmesi halinde yukarı yönlü hareketlilikteki azalmanın üçte ikisi bertaraf edebilir.

${ }^{4}$ https://opportunityinsights.org 
Aktarılan değerlendirmeler 1şığında Case ve Deaton'in, Sennett'in ve Chetty'nin vargılarının bir noktada kesiştiğini yorumlamak olanaklıdır. Tüm araştırmacılar değişen bölüşüm dinamiklerini problemin kökenine yerleştirmekte ve emekçilerin dezavantajlı pozisyonlarını bu minvalde mütalaa etmektir. Son tahlilde deneyimlenen buhrandan kurtulmak için yerleşik iktisat kuramı çerçevesinde ötelenen bölüşüm odaklı analiz araçlarının geri çağrılması gerektiğini değerlendirmek mümkündür. 


\section{Kaynakça}

Can, C. (2005). “Opioid Analjezikler”. Türkiye Klinikleri Dabili T⿰р Bilimleri Dergisi, 1(9):15-23.

Case, A. ve Deaton, A. (2020). Deaths of Despair and the Future of Capitalism. Princeton: Princeton University Press.

Deaton, A. (2013). The Great Escape: Health, Wealth, and the Origins of Inequality. Princeton University Press, Princeton.

Sennett, R. (1998). The Corrosion of Character. W.W. Norton, New York.

Sennett, R. (2017). Karakter Aşınması. Ayrıntı Yayınları, İstanbul.

Sennett, R. ve Cobb, J. (1972). The Hidden Injuries of Class. Knopf, New York. 